\title{
IRON FERTILIZATION OF KENTUCKY BLUEGRASS
}

\author{
David J. Wehner and Jean E. Haley \\ Department of Horticulture \\ University of Illinois \\ 1201 S. Dorner Drive \\ Urbana, Illinois 61801
}

\section{ABSTRACT}

Iron applications are sometimes used to enhance the color (darker green) of turfgrass stands even when iron is not deficient. A study was conducted to determine the feasibility of replacing a portion of the total yearly $\mathrm{N}$ applied to Kentucky bluegrass (Poa pratensis L.) with iron. Turfgrass response to iron chelate (Sequestrene 330) applications at $2.2 \mathrm{~kg} \mathrm{Fe} \mathrm{ha}{ }^{-1}$ in combination with three liquid-applied $\mathrm{N}$ sources (urea, Formolene, and FLUF) at $25 \mathrm{~kg} \mathrm{~N} \mathrm{ha-1}$ was compared to turf response from applications of the $\mathrm{N}$ sources at $49 \mathrm{~kg} \mathrm{~N}$ ha-1. Iron was substituted for part of the $\mathrm{N}$ in either the first and second, second and third, or third application in a four application per year program. The study was conducted for three years, and the fertilized turf was rated for color weekly during the growing season. Depending on $\mathrm{N}$ source and frequency of $\mathrm{Fe}$ application, turf treated with $\mathrm{N}$ received higher color ratings compared to turf 
receiving $\mathrm{Fe}+\mathrm{N}$ on 13 (Formolene $+\mathrm{Fe}$ in thira application) to 36\% (Fluf $+\mathrm{Fe}$ in first and second application) of the rating dates. Turf color was judged acceptable on 78 to $85 \%$ of the rating dates for turf treated with $\mathrm{N}$ and 62 to $85 \%$ of the rating dates for turf treated with $\mathrm{Fe}+\mathrm{N}$. The results indicate that it is feasible to substitute iron for a portion of the $\mathrm{N}$ in a urea or Formolene fertilization program but that caution should be used when replacing $\mathrm{N}$ from FLUF with iron.

\section{INTRODUCTION}

In Illinois, Fe deficiencies are rarely associated with turfgrass stands. However, there is interest in using Fe as a foliar spray to enhance (darker green) the color of turf and reduce the amount of $\mathrm{N}$ fertilization. Nitrogen fertilization can sometimes lead to excessive shoot growth, a reduction in root growth or decreased stress tolerance. Iron has been used to enhance the color of centipedegrass (Eremochloa ophiuroides (Múnro.) Hack.) (1), creeping bentgrass (Agrostis palustris L.) (2), and Kentucky bluegrass (3).

Our previous research (3) indicated that the color of Kentucky bluegrass was acceptable where iron was applied in combination with $\mathrm{N}$ from urea. Applications of Fe with and without $\mathrm{N}$ were made during different times of the year to different sets of plots. The length of the response was direct $1 Y$ proportional to the weather conditions present at the time of application. In 
the spring, when growth of the plants was rapid, the effect of the Fe was short lived; in the fall, when the turf was growing slowly due to cool weather, the effect lasted several months. The most effective iron treatment was an application of iron chelate at a $2.2 \mathrm{~kg} \mathrm{Fe} \mathrm{ha} \mathrm{h}^{-1}$ rate. With most applications, turf response to Fe dissipated at approximately the same time as the $\mathrm{N}$ response due to the urea application. Thus, it was difficult to get a true estimate of how $\mathrm{Fe}$ would integrate into a fertilization program consisting of four applications of $\mathrm{N}$ per year to the same plots. The purpose of this research was to further examine the use of Fe on Kentucky bluegrass. Specifically, we were interested in determining if it was feasible to substitute $\mathrm{Fe}$ for $\mathrm{N}$ on a regular basis in a fertilization program similar to that used by the lawn care industry. A second objective was to determine if $\mathrm{Fe}$ use was compatible with Formolene and FLUF, two liquid $\mathrm{N}$ sources used by the lawn care industry.

MATERIALS AND METHODS

This study was started on 3 May 1985 and concluded on 3 October 1987. A Kentucky bluegrass stand consisting of a blend of the cultivars Parade, Adelphi, Glade, and Rugby growing on a Flanagan silt loam soil (fine, montmorillonitic, mesic Aquic Argiudoll) was used for this research. Plots measuring $0.9 \times 3.1$ m were established in a randomized complete block design with three replications. The plots were irrigated as necessary to prevent drought stress and mowed one time per week at a height of 
$5.0 \mathrm{~cm}$ with clippings collected. The treatments were applied with a $\mathrm{CO}_{2}$ powered sprayer with water $\left(1629 \mathrm{I} \mathrm{ha}^{-1}\right)$ as the carrier. The $\mathrm{N}$ sources were urea $(46-0-0)$, FLUF (18-0-0, suspension fertilizer consisting of low molecular weight water-soluble and water-insoluble ureaformaldehyde reaction products in which $35 \%$ of the $\mathbb{N}$ is free urea, W. A. Cleary, Somerset, NJ); and Formolene (30-0-2, solution fertilizer consisting of a low molecular weight, water soluble, ureaformaldehyde reaction product containing approximately 50\% free urea with the remainder being methylol and soluble methylene urea, Hawkeye Chemical Co., Clinton, IA). The iron source was Sequestrene 330 (10\% iron, sodium ferric diethylenetriamine pentaacetate). The treatments and dates of application are indicated in Table 1.

Previous research (3) indicated that there was no growth response, as measured by clipping collection, due to iron application to Kentucky bluegrass growing on the Flanagan soil. The primary response was a change in turfgrass color. Therefore, for this research, color ratings were used as the indicator of treatment response. Color ratings were taken on a weekly basis throughout the growing season using a scale of 1 to 9 with 1=yellow color and 9=dark green. Color was judged acceptable when the turf received a rating of 7 or higher. Color ratings for each date were subjected to an analysis of variance, and means were compared using single degree of freedom contrasts. 
TABLE 1. Treatment compasition and application timings and number of dates color was considered acceptable (rating >7.0). Color was rated on 61 dates using a scale of 1 to 9 with $1=$ yellow and $9=$ dark green turfgrass color.

\begin{tabular}{|c|c|c|c|c|c|c|c|c|c|}
\hline \multirow[b]{2}{*}{ Treatment } & \multicolumn{8}{|c|}{ Application Dates } & \multirow{2}{*}{$\begin{array}{l}\text { No. Dates } \\
\text { when turf } \\
\text { color was } \\
\text { acceptable }\end{array}$} \\
\hline & $\begin{array}{rl}3 & M \\
21 & M \\
6 & M\end{array}$ & $\begin{array}{l}85 \\
86 \\
87\end{array}$ & \multicolumn{2}{|c|}{$\begin{array}{r}2 \text { July } 85 \\
15 \text { July } 86 \\
8 \text { July } 87\end{array}$} & \multicolumn{2}{|c|}{$\begin{array}{r}8 \text { Aug. } 85 \\
28 \text { Aug. } 86 \\
24 \text { Aug. } 87\end{array}$} & \multicolumn{2}{|c|}{$\begin{array}{r}23 \text { oct. } 85 \\
8 \text { oct. } 86\end{array}$} & \\
\hline & \multicolumn{9}{|c|}{$\cdots-\cdots-\cdots-\cdots$ Kg ha ${ }^{-2}-\ldots-\cdots$} \\
\hline & $\underline{\mathrm{Fe}}$ & $\underline{\mathbf{N}}$ & $\underline{\mathrm{Fe}}$ & $\underline{\mathrm{N}}$ & $\underline{\mathrm{Fe}}$ & $\underline{N}$ & $\underline{\text { Fe }}$ & $\underline{\mathbf{N}}$ & \\
\hline Formolene & & 49 & & 49 & & 49 & & 49 & 48 \\
\hline Formolene/ $\mathrm{Fe}_{1,2}$ & 2.2 & 25 & 2.2 & 25 & & 49 & & 49 & 43 \\
\hline Formolene $/ \mathrm{Fe}_{2,3}$ & & 49 & 2.2 & 25 & 2.2 & 25 & & 49 & 44 \\
\hline Formolene/Fe $\mathrm{F}_{3}$ & & 49 & & 49 & 2.2 & 25 & & 49 & 47 \\
\hline FLUF & & 49 & & 49 & & 49 & & 49 & 51 \\
\hline $\mathrm{FLUF} / \mathrm{Fe}_{1,2}$ & 2.2 & 25 & 2.2 & 25 & & 49 & & 49 & 40 \\
\hline $\mathrm{FLUF} / \mathrm{Fe}_{2,3}$ & & 49 & 2.2 & 25 & 2.2 & 25 & & 49 & 38 \\
\hline $\mathrm{FLUF} / \mathrm{Fe}_{3}$ & & 49 & & 49 & 2.2 & 25 & & 49 & 42 \\
\hline Urea & & 49 & & 49 & & 49 & & 49 & 52 \\
\hline Urea/Fe, $\mathrm{Fe}_{1,2}$ & 2.2 & 25 & 2.2 & 25 & & 49 & & 49 & 52 \\
\hline Urea $/ \mathrm{Fe}_{2,3}$ & & 49 & 2.2 & 25 & 2.2 & 25 & & 49 & 47 \\
\hline Urea/Fe 3 & & 49 & & 49 & 2.2 & 25 & & 49 & 52 \\
\hline Check & & & & & & & & & 1 \\
\hline
\end{tabular}




\section{RESULT'S *AND DISCUSSION}

Most of the fertilization programs provided good turfgrass response as indicated by the large number of dates when color was acceptable (Table 1). With the substitution of $\mathrm{Fe}$ into the Formolene or FLUF based programs, the number of dates when color was acceptable declined. The greatest decline occurred when Fe was substituted for FLUF-N in the second and third application $\left(\mathrm{FLUF} / \mathrm{Fe}_{\mathbf{2}, 3}\right)$. The turf fertilized with FLUF + Fe received low color ratings during the middle to later portion of the growing season. The low ratings were probably related to the fact that FLUF, unlike urea or Formolene, contains some water-insoluble N. Water-insoluble $\mathrm{N}$ generally becomes available at the end of the fertilizer response period and may provide some residual for later in the growing season. By reducing the amount of FLUF-N applied in the first and second or second and third application, there was a reduction in turf color ratings during July and August.

The programs where $\mathrm{Fe}$ was substituted for urea $\mathrm{N}$ in the first and second applications or in the third application provided acceptable color on 52 dates which was equal to the program containing only urea.

The results of the single-degree-of-freedom comparisons for color ratings between turf receiving $\mathrm{N}$ and turf receiving the $\mathrm{Fe}+$ $\mathrm{N}$ are presented in Table 2 . When significant differences occurred, the turf treated with the full rate of $\mathrm{N}$ usually received a higher color rating than the turf that received the $\mathrm{N}+$ Fe. The lower color ratings for turf receiving $\mathrm{Fe}$ were given 
TABLE 2. Frequency of significant differences between treatments on Kentucky bluegrass as determined by single-degree-of-freedom contrasts. Subscripts following $\mathrm{Fe}$ indicate in which applications iron was substituted for a portion of the $N$. Color was rated on 61 dates using a scale of 1 to 9 with 1 =yellow and $9=$ dark green turfgrass color.

Treatment I vs. Treatment II

\begin{tabular}{|c|c|}
\hline & ings \\
\hline & $I>I I^{\prime \prime}$ \\
\hline
\end{tabular}

\begin{tabular}{|c|c|c|c|c|c|}
\hline \multirow[t]{4}{*}{ Formolene } & Formolene/Fe $e_{1,2}$ & 1985 & 7 & 0 & 16 \\
\hline & & 1986 & $\mathbf{0}$ & 3 & 14 \\
\hline & & 1987 & 8 & 0 & 13 \\
\hline & & Total & 15 & 3 & 43 \\
\hline \multirow[t]{4}{*}{ Formolene } & Formolene/Fe 2,3 & 1985 & 7 & 0 & 16 \\
\hline & & 1986 & 1 & 2 & 14 \\
\hline & & 1987 & 5 & 1 & 15 \\
\hline & & Total & 13 & 3 & 45 \\
\hline \multirow[t]{4}{*}{ Formolene } & Formolene/Fe 3 & 1985 & 3 & 0 & 20 \\
\hline & & 1986 & 2 & 2 & 13 \\
\hline & & 1987 & 3 & 1 & 17 \\
\hline & & Total & 8 & 3 & 50 \\
\hline \multirow[t]{4}{*}{ FLUF } & $\mathrm{FLUF} / \mathrm{Fe}_{1,2}$ & 1985 & 9 & 1 & 13 \\
\hline & & 1.986 & 2 & 2 & 13 \\
\hline & & 1987 & 11 & 0 & 10 \\
\hline & & Total & 22 & 3 & 36 \\
\hline \multirow[t]{4}{*}{ FLUF } & $\mathrm{FLUF} / \mathrm{Fe}_{2,3}$ & 1.985 & 10 & 1 & 12 \\
\hline & & 1986 & 2 & 2 & 13 \\
\hline & & 1987 & 5 & 0 & 16 \\
\hline & & Total & 17 & 3 & 41 \\
\hline \multirow[t]{4}{*}{ FLUF } & $\mathrm{FLUF} / \mathrm{Fe}_{3}$ & 1985 & 8 & 2 & 13 \\
\hline & & 1986 & 0 & 1 & 16 \\
\hline & & 1987 & 4 & 1 & 16 \\
\hline & & Total & 12 & 4 & 45 \\
\hline \multirow[t]{4}{*}{ Urea } & Urea/Fe,, 2 & 1985 & 4 & 0 & 19 \\
\hline & & 1986 & 0 & 4 & 13 \\
\hline & & 1987 & 6 & 0 & 15 \\
\hline & & Total & 10 & 4 & 47 \\
\hline \multirow[t]{4}{*}{ Urea } & Urea/Fe ${ }_{2,3}$ & 1985 & 9 & 1 & 13 \\
\hline & & 1986 & 1 & 3 & 13 \\
\hline & & 1987 & 5 & 0 & 16 \\
\hline & & Total & 15 & 4 & 42 \\
\hline
\end{tabular}


TABLE 2, continued.

\begin{tabular}{|c|c|c|c|c|}
\hline Urea & Urea/Fe 3 & 1985 & 5 & 2. \\
\hline & & 1986 & 1 & 1 \\
\hline & & 1987 & 2 & 0 \\
\hline & & Total & 8 & 3 \\
\hline Urea & Formolene & 1985 & 1 & 0 \\
\hline & & 1986 & 2 & 0 \\
\hline & & 1.987 & 2 & 0 \\
\hline & & Total & 5 & 0 \\
\hline Urea & FLUF & 1985 & 4 & 1 \\
\hline & & 1986 & 4 & 0 \\
\hline & & 1987 & 3 & 0 \\
\hline & & Total & 11 & 1 \\
\hline FLUF & Formolene & 1985 & 2 & 2 \\
\hline & & 1986 & 0 & 1 \\
\hline & & 1987 & 1 & 1 \\
\hline & & Total & 3 & 4 \\
\hline
\end{tabular}

$\overline{p=0.05}$

during periods when temperatures and rainfall were favorable for growth. The relationship between growing conditions and the length of iron response found in this study paralleled the findings in our earlier research (3).

The substitution of $\mathrm{Fe}$ for F'LUF-N resulted in lower color ratings more frequently than when $\mathrm{Fe}$ was substituted for urea-N or Formolene-N. Because the substitution of $\mathrm{Fe}$ for $\mathrm{N}$ in FLUF-N programs resulted in both a decline in the number of dates when color was considered acceptable and significantly lower color ratings on 12 to 22 rating dates, this substitution must be considered questionable and is not recommended. Although there were significant differences in turf color when $\mathrm{Fe}$ was substituted for urea or Formolene-N, the number of dates when color was considered acceptable did not decline drastically, and therefore, 
IRON FERTILIZATION OF KENTUCKY BLUEGRASS

the substitution of $\mathrm{Fe}$ for $\mathrm{N}$ in these programs was considered feasible.

\section{CONCLUSION}

There are benefits in reducing the amount of $\mathrm{N}$ applied to turfgrass stands, however, dissatisfaction can result if the turf appearance is drastically affected. The results of this research indicate that it is possible to substitute $\mathrm{Fe}$ for $\mathrm{N}$ in urea or Formolene fertilization programs without greatly affecting the appearance of the turf. However, the effect on color due to substituting Fe for FLUF-N should only be considered when the benefits of reducing $\mathrm{N}$ application outweigh the effect on color.

\section{REFERENCES}

1. Carrow, R. N., B. J. Johnson, and G. W. Landry, Jr. 1988. Centipedegrass response to foliar application of iron and nitrogen. Agron. J. 80:746-750.

2. Snyder, V., and R. E. Schmidt. 1974. Nitrogen and iron fertilization of bentgrass. Proc. Int. Turfgrass Res. Conf. $2: 176-185$.

3. Yust, A. K., D. J. Wehner, and T. W. Fermanian. 1984. Foliar application of $\mathrm{N}$ and $\mathrm{Fe}$ to Kentucky bluegrass. Agron. J. $76: 934-938$. 